\title{
Does the Expansion of Interbank Business Diminish the Liquidity of Banks in China?
}

\author{
Zhengsheng Xu \\ Jinan University, Guangzhou, China \\ Email: xzs0317@163.com
}

How to cite this paper: Xu, Z. S. (2017) Does the Expansion of Interbank Business Diminish the Liquidity of Banks in China? Chinese Studies, 6, 12-23.

https://doi.org/10.4236/chnstd.2017.61002

Received: January 18, 2017

Accepted: February 17, 2017

Published: February 20, 2017

Copyright (C) 2017 by author and Scientific Research Publishing Inc. This work is licensed under the Creative Commons Attribution International License (CC BY 4.0).

http://creativecommons.org/licenses/by/4.0/

\section{(c) (†) Open Access}

\begin{abstract}
The interbank business gradually becomes one of the main businesses of a bank. The interbank business has great influence on the liquidity of banks. This article makes use of the panel data of twenty-three different types of business banks from 2009 to 2015 to analyze the relationship between interbank business and the liquidity of banks and the factors that affect the bank liquidity. The results show that the interbank business affects the liquidity of banks through three impact paths which are maturity mismatch, the allocation of funds and meaningless capital turnover. Besides, the relationship between the interbank business and bank liquidity is negative, and the expansion of interbank business would result in the decrease of liquidity level.
\end{abstract}

\section{Keywords}

Commercial Bank, Interbank Business, Liquidity Risk

\section{Introduction}

The scale of interbank business is keeping expansive and the mode of interbank business is keeping innovating. As a result, the banks gain much more profits and strength its management. In 2014, central bank of China along with CBRC and State Administration of Foreign Exchange published the Regulation NO. 127. That Regulation clarifies the definition of interbank business: interbank business refers to the financial system of trading currencies among banks and financial institutions, excluding retail investors and smaller trading parties. While some interbank trading is done by banks on behalf of large customers, most interbank trading is proprietary, meaning that it takes place on behalf of the banks' own accounts. To be specific, the interbank business includes interbank borrowing business, interbank placement, interbank wealth management and so on. 
With the intensity of financial regulations and laws on the credit \& loan in China, the interbank business brings numerous benefits to the banks. On one hand, the development of interbank business brings vitality to the financial industry and makes the operating situations better. On the other hand, the fastmoving capital satisfies the various demands from the real economy. Just as the central bank of China stated, Innovation and rapid growth in interbank businesses have played an important role in facilitating liquidity management, improving financial resources allocation and supporting the real economy, according to the central bank statement.

However, the way the banks develop interbank business remains numerous potential risk, weakens the effect of the regulations and makes negative influence to the financial system (Calvo \& Reinhart, 1999). Recognizing the interbank business correctly and figuring out the potential risks triggered by the business are of great importance.

\section{The Present Situation of Interbank Business}

At the very beginning, the interbank business was meant to solve the shortage of banks liquidity. For instance, the banks can use the interbank borrowing business to fulfill their positions. However, in recent years, with the innovations of the business modes, the interbank business is no longer only a way to adjust the liquidity situation but a major business to make great profits and expand the banks scale.

According to the Chinese Statistical Office, the scale of interbank asset business among all the banks in China has reached 52,500 billion which increases $18.56 \%$ compared to the same period of 2015 . The size of interbank liability business is 28,500 billion which increases 1600 billion compared to last year. What's more astonishing, at the beginning of interbank business burst, which was 2010, the size of interbank asset business now is almost four times as much as the scale of 2010. At the same time, the interbank liability business reaches 28,500 billion from 8600 billion.

Since the fast-growing business brings some negative influences to the financial system, the related regulators released several policies to normalize the nonstandard aspects. Therefore, in some years, the velocity of inter-bank business would slow down. However, generally speaking, the speed of the development of this business is increasingly fast.

We can analysis this question from the perspective of growth. Table 1 shows the comparison between the growth rate of interbank business and other bank business. As it shows, at first the two variables vary at the same way. Then the growth rate of interbank business speed up a lot, which is way faster than the other bank business. Although, the rate slows down when there were some regulations to limit its growth, it would speed up again after some innovations.

So, from both the total amount and the growth rate, the development of interbank business is much better than the other bank business. Although there would always be a slow-down when the new regulations published, there's al- 
Table 1. The growth rate comparison between interbank business and other bank business.

\begin{tabular}{ccc}
\hline date & The rate of interbank business & The rate of other bank business \\
\hline $2009-06$ & 29.59 & 26.88 \\
$2009-12$ & 30.28 & 25.59 \\
$2010-06$ & 36.21 & 15.24 \\
$2010-12$ & 34.20 & 16.19 \\
$2011-06$ & 37.44 & 14.87 \\
$2011-12$ & 38.66 & 14.45 \\
$2012-06$ & 41.22 & 14.56 \\
$2012-12$ & 34.50 & 13.55 \\
$2013-06$ & 16.36 & 13.41 \\
$2013-12$ & 15.82 & 13.57 \\
$2014-06$ & 23.19 & 13.51 \\
$2014-12$ & 17.69 & 11.61 \\
$2015-06$ & 14.80 & 11.58 \\
$2015-12$ & 25.21 & 12.83 \\
\hline
\end{tabular}

Data source: the People Bank of China.

ways countermeasures to the policies, with the innovations of the business, the scale of interbank business expands again. What's worse, the expansion of the business may affect the core segment of a bank-liquidity.

The gap between the interbank asset business and the interbank liability business is increasingly large. The reasons for this phenomenon are various. But the direct factor would be the maturity mismatching of assets and liabilities. In fact, date back to 2013, when the cash crush phenomenon broken out, academic community believed that the cash crush had some relations with the expansion of interbank business.

There are a bunch of reasons when it comes to the shortage of liquidity in a bank. In fact, every single bank business may cause the liquidity risk. To be more specific, the reasons can be separated into two aspects: the internal factors and external factors. This article would also analysis the relationship between the interbank business and bank liquidity situation from those two aspects.

The transmission mechanism from the interbank business to the shortage of liquidity in the bank industry can be concluded as the following aspects.

\subsection{The Maturity Mismatching Causes the Shortage of Liquidity}

At first, the interbank business is an effective way to adjust the position of a bank. When there is a shortage of liquidity in a bank, the bank can make use of the interbank borrowing business to fulfill its demand (Diamond \& Philip, 1983). However, with the development and innovation of interbank business, the nature of this business has changed. For instance, when the liquidity squeezes in the financial system, the bank should have token some measures to adjust its position, like interbank borrowing business. But the rates would go up during the liquidity squeezing. Apparently it is a good chance to do the interbank business 
to make great profit. As a result, there is a contradiction between the liquidity and profitability.

In fact, one of the reasons that the interbank business expanded in such a short time is this business can bring numerous benefits. The traditional deposit and loan business in China doesn't highly rely on the maturity mismatching because there was interest rate difference protect policy in the past. The banks can make big money without high risk. But now, the interbank business market is almost a Perfectly Competitive Market. The mismatch is the lifeblood of the interbank business. Especially in 2011, with the financial innovation, a lot of nonstandard asset which is not easy to be traded in a standard market, is subordinated to the interbank business.

Because the development of financial market in China is not perfect, the banks can find a lot of new ways to make profits.

\subsection{The Orientation of the Investment May Cause the Shortage of Liquidity}

From the analysis of the actual use of interbank business funds, quite a lot of the capital poured into the high risk field that is not easy to get loans through the normal deposit and loan business (Friedman \& Schwartz, 1986). For example, the real estate enterprise, local government investment platform and some Excess capacity enterprise are the potential receiver of the interbank funds. The reasons why these subjects can be the target of the banks are various. But the most important one is that their needs are highly consistent with the risk preference of banks.

What's more, the banks can use the interbank business move the on-balance sheet items to the off-balance sheet items. By doing this, the banks can bypass the regulation from the central bank and achieve the banks goals.

On the other hand, interbank funds are also an important support for the shadow bank. Some banks use the interbank business to raise capital and directly or indirectly invest those capitals to the small loan companies, security companies, fund companies.

In addition there is a considerable part of the interbank business funds remained in the financial institutions. The funds cannot really pour into the real economy which reduces the efficiency of funds and pushes up the cost of capital. From these three kinds of potential capital flow directions, the misuse of the interbank funds have become an important factor to the macro-control and market supervision failure and can also lead to bank liquidity problems.

\subsection{The Funds Pointlessly Cycle in the Financial System Cause the Shortage}

The traditional deposit and loan business of commercial banks is the main support of the real economy. Given the character of the deposit and loan business: the market participants are numerous, the customer demand is universal and extensive. Although the D\&L business is also affected by the macroeconomic 
cycle, but only in a certain period of time.

But the interbank business is not the same case. That kind of business is relative free from the real economy and mainly cycled in the financial markets. Moreover, the clients of interbank business are concentrated. The supply and demand of this business is relatively convergence. In addition, in recent years, the scale of financial management products surge, the size of the interbank business between financial institutions has gone up, but the corresponding assets are often real estate-related, stock bonds and other non-standard assets. As a result, once the corresponding asset prices fell sharply, it may result in systemic risk within the financial system. In addition, it is because the core of the interbank business is mismatch business model. If all banks are take such a business model can be expected within the bank system is very large amount of money, which also shows why the cash crush in 2013 only within the bank, and other financial institutions did not appear such a crisis.

\section{The Driving Factors of the Interbank Business Fast-Growing Development}

The reasons of the rapid development of the interbank business are various. But briefly it is nothing less than the internal financial institutions for the objective needs of liquidity, the capital profitability, and regulation circumvention.

\subsection{Liquidity Adjustment}

The interbank business was originally used as a tool for adjusting the positions in commercial banks and used to ease liquidity pressure in the face of liquidity shortage. In the modern commercial bank business model, the balance between income and risk probability is something that banks must be carefully weighed (Freixas, Parigi, \& Jean-Charles, 2000; Ercegovac \& Kundid, 2013). How to minimize the provision of deposit reserve without affecting the normal operation and how to expand the scale of asset returns are the ideal business models for banks. At this time, interbank borrowing and other business tools make it possible. The banks cannot maintain a large amount of reserves to fulfill its need. This is the original function of the interbank business, which is meant to improve the use of funds for the real economy and continuously create profitability and liquidity of commercial banks.

\subsection{The Bank Industry Is a Profit-Driven Industry}

Nowadays, commercial banks are increasingly competitive in the all of the different business, with the marketization of interest rates. Commercial banks in the past can get a lot of money profit through the deposit and loan business. In addition, as the economy prevailed, the price index climbed steadily, bank deposits were no longer the first option for the public to consider. More and more financial institutions utilize the continuous innovation of financial products to compete with banks. As a result, it can be said that the financial "disinfecting" process continues to intensify (Gabriele, Amin, Mauro, \& Dirk, 2013). Commer- 
cial banks can no longer rely too much on deposits and other passive debt business. They would better look for expansion of active debt channels. It can be said that the stimulus brought by the interbank business to promote the bank's innovation and reform, to promote the process of state-owned banks mixed reform, commercial banks pay more attention to profit, market ranking and other banks as a financial institution development.

On the other hand, for small and medium-sized banks, the interbank business is an important tool for the rapid expansion of asset size. For small and medium-sized businesses, expanding with the help from the stock market is the most economical way of financing. To meet the conditions of listing and to prepare for the IPO is the city-commercial banks' short-term development goals. Therefore, rapid expansion of asset size to meet the listing requirements has become a top priority. The expansion of the scale requires an increase in the number of loans, the extensive laying of outlets, the establishment of off-site sub-branches, or the interbank business model. Obviously, the use of interbank business to expand the scale of business is the most "simple and fast" approach. Small and medium-sized businesses will use the high yield of the interbank business financial products issued.

\subsection{Financial Industry Assemblage Superiority}

As a trend of the development of the financial industry, the mixed operation of financial institutions is one of the goals of China's financial reform and innovation (Wang Peng, 2013). At present, China's financial industry still implements the financial sub-sector management system. With the formation of public awareness and other factors gradually change. Securities companies, fund companies, trust companies and other assets increased year by year. Under this circumstance other financial institutions need more cooperation with banks, while banks can also through this way to carry out bank-security cooperation, bank-funds cooperation and bank-insurance cooperation to earn intermediate income. This cross-border crossing of financial products, commercial banks off-balance sheet business model has the mixed business prototype. Under this system, the cooperation between banks and many financial institutions provides a pre-exploration experience for the future development trend of the financial industry. Through the practice of the way to constantly explore the road of reform of the financial system to explore the mode of development of mixed business model is feasible and effective way.

\subsection{Regulatory Arbitrage}

There are many ways to use arbitrage in the interbank business. According to their different operating modes, they can be divided into three types: use the change of accounting subjects to arbitrage, the interbank business financial connection with non-standard assets for off-chip arbitrage and interbank investment with different SPV arbitrage (He Yujie, Zhai Guangyu, \& Sun Xiaoxia, 2015). The initial meaning of regulation arbitrage is not a violation of regulatory 
provisions but a neutral word is not derogatory, can be regarded as a financial innovation, is the current division of business management model of innovation. This kind of arbitrage has not only promoted the continuous innovation of the interbank business, but also for the future mixed operation era of the regulatory model provides a pioneering experience.

But everything has two sides, especially when the US sub-prime mortgage crisis evolved into a global crisis, the regulatory arbitrage gradually considered negative. The frequent occurrence of regulatory arbitrage will have a negative impact on the regulation and result in frequent violations of the financial system caused by the turbulence, cause unfair competition; the other hand, the use of interbank business can be converted into off-balance sheet assets The central bank and other regulators can not accurately calculate such as the scale of social financing, corporate financing costs and other issues cannot be accurate macro-control.

But everything has two sides, especially when the US sub-prime mortgage crisis evolved into a global crisis, the regulatory arbitrage gradually considered negative (Georg, 2013). The frequent occurrence of regulatory arbitrage will have a negative impact on the regulation and result in frequent violations of the financial system caused by the turbulence, cause unfair competition; the other hand, the use of interbank business can be converted into off-balance sheet assets The central bank and other regulators can not accurately calculate such as the scale of social financing, corporate financing costs and other issues cannot be accurate macro-control.

\subsection{Regulatory Circumvention}

Since the 2008 financial crisis, the China government issued " 4 trillion" fiscal policy which brought abundant credit scale. With the influence of money multiplier, the bank's asset size surge has brought rapid credit expansion, followed by endless bad debts. Central bank, China Banking Regulatory Commission and other regulators began to take measures to curb the rapid expansion of credit scale, various regulatory restrictions was used such as the deposit and loan ratio (now has been abolished), as well as credit scale, risk weight constraints and leverage rate limit, provision coverage rate and so on. Although the revised commercial bank law in 2015 has canceled the deposit and loan ratio, but here is the reason for the rapid growth of the interbank business. And initially bypassed the deposit and loan ratio assessment, ignored the credit scale is an important reason. Commercial banks through the interbank business will be the original form of credit business into off-balance sheet business that is converted by accounting subjects, the loan into such as buying and selling financial assets, accounts receivable and other subjects to bypass the past deposit and loan ratio limit. Second, through the interbank business, business can also bypass the regulatory funds will be invested in the type of bank preference enterprises. Commercial bank preference customer resources include local financing platform, real estate enterprises and some excessive capacity industry. Because these companies often ignore the level of interest rates, only pay attention to performance. Like the real 
estate companies, they can afford higher cost of financing, and because the real estate industry in the past can be profiteering. However, due to deposit and loan ratio, credit size and loan restrictions, banks often cannot get their wish. At this time, through the interbank business, business can circumvent supervision, to complete the transaction.

\section{Model}

\subsection{The Set of the Model}

In order to study the impact of the interbank business of commercial banks on the liquidity risk of banks, we construct the following model:

$$
\begin{aligned}
L S= & \beta_{0}+\beta_{1} \text { Interasset }_{i t}+\beta_{2} \text { Interliability }_{i t}+\beta_{3} \text { Captial }_{i t}+\beta_{4} C / I_{i t} \\
& +\beta_{5} G D P_{t}+\beta_{6} M_{2_{t}}+\beta_{7} R O A_{i t}
\end{aligned}
$$

\subsection{Data Source}

This paper will use panel data to analysis the relationship between the liquidity and the scale of interbank business. Select the 2009-2015 China's 21 commercial banks panel data, including state-owned commercial, joint-stock banks, city bank and rural and commercial banks. The data comes from the annual reports of banks, the bankscope database, and the National Bureau of Statistics (Table $2 \&$ Table 3).

Table 2. The Variables.

\begin{tabular}{cc}
\hline Variables & The meaning of these variables \\
intersse & The port \\
interliablity & Interbank liabilities/total liabilities \\
Capital & Bank owned capital/risk weighted assets \\
$R O A_{i t}$ & Net profit/average total assets \\
$C O I N_{i t}$ & Cost/income \\
$\operatorname{Impairloan}_{i t}$ & Total bad loans/loans \\
$\mathrm{GDP} / G D P_{t-1}-1$ & GDP growth rate \\
$\mathrm{M}_{2} / \mathrm{M}_{\mathrm{t}-1}-1$ & Broad money growth rate \\
$L Q_{i t}$ & Liquidity level
\end{tabular}

Table 3. Descriptive statistics.

\begin{tabular}{cccccc}
\hline Variable & Sample & Mean & Standard deviation & Min & Max \\
\hline ls & 161 & 0.0814 & 1.132 & -3.290 & 2.210 \\
interasset & 161 & 0.121 & 0.0685 & 0.0100 & 0.350 \\
interliability & 161 & 0.167 & 0.0854 & 0.03 & 0.480 \\
capitial & 161 & 12.16 & 2.077 & 0.120 & 17.23 \\
cr & 161 & 33.36 & 6.182 & 21.59 & 49.79 \\
gdp & 161 & 8.414 & 1.265 & 6.900 & 10.60 \\
m2 & 161 & 16.39 & 5.455 & 12.20 & 28.50 \\
roa & 161 & 1.16 & 0.732 & 0.64 & 1.45 \\
\hline
\end{tabular}


The data in this paper is a balanced panel data, showing a short T-long $\mathrm{N}$ shaped short plate data form. In this case, because the $\mathrm{T}$ is smaller, so there is no discussion of whether there is an autocorrelation. Generally assumed it is independent and identically distributed.

\subsection{The Regression Result}

The regression results in Table 4 show that the relationship between the core explanatory variables and the level of liquidity is always negatively correlated and at a significant significance level of $10 \%$ in the case of the addition of different control variables; the other core The variable interbank liabilities are positive only in model 5, but are not significant and are significant in other models and have a negative correlation with the level of liquidity. This illustrates the negative correlation between interbank business and liquidity levels, reflecting the liquidity problems associated with the rapid expansion of interbank business. As in the previous analysis of the internal mechanism between the expansion of the interbank business and liquidity, rapid expansion will affect the flow through more severe deadline mismatches, capital flows to less liquid assets, and more money in the way of financial institutions. Through the analysis of the money shortage in 2013 , it is possible to draw the impact of the rapid expansion of the interbank business on liquidity.

The capital adequacy ratio can be seen as the ratio of the owner's equity to the asset (i.e., the asset-liability ratio), as any firm, if the higher asset-liability ratio is lower, the potential risk of capital adequacy. In theory, the capital adequacy ratio is positively related to the bank's liquidity level. The empirical results of the model also illustrate this: in the model 1 and model 6 , the capital adequacy ratio has always been positively correlated with the level of liquidity, in line with the relationship between capital adequacy ratio and liquidity level, indicating that the higher the capital adequacy ratio, The stronger the ability of banks to resist risks.

Table 4. The result of the regression.

\begin{tabular}{|c|c|c|c|c|c|c|}
\hline & model 1 & model 2 & model 3 & model 4 & model 5 & model 6 \\
\hline Interasset & $-2.402^{*}(-1.98)$ & $-1.619(-1.41)$ & $-1.475(-1.27)$ & $-2.210^{*}(-1.99)$ & $-2.477^{\star \star}(-2.62)$ & $-1.201(-1.89)$ \\
\hline Interliability & $-5.845^{\star * *}(-5.84)$ & $-6.881^{* * *}(-6.88)$ & $-6.934^{\star * *}(-6.94)$ & $-6.732^{* * *}(-6.85)$ & $0.0255(-0.03)$ & $-1.517^{\star}(-2.43)$ \\
\hline Capital & $0.0731^{\star}(-2.18)$ & & & & & $0.0454^{*}(-2.4)$ \\
\hline gdp & & & $-0.123^{\star \star}(-2.59)$ & & & $-0.141^{\star * *}(-3.87)$ \\
\hline $\mathrm{m} 2$ & & & & $-0.0253^{*}(-2.38)$ & & $-0.0276^{\star *}(-3.17)$ \\
\hline roa & & & & & $0.103^{* * *}(-9.38)$ & $0.128^{\star * \star}(-19.87)$ \\
\hline _cons & $0.457(-1.05)$ & $2.380^{\star \star \star}(-4.97)$ & $2.451^{\star \star \star}(-5.07)$ & $1.885^{\star \star \star}(-5.82)$ & $-4.987^{\star * *}(-7.24)$ & $-4.640^{\star * *}(-8.01)$ \\
\hline Method & $\mathrm{FE}$ & $\mathrm{FE}$ & $\mathrm{FE}$ & $\mathrm{FE}$ & $\mathrm{FE}$ & $\mathrm{FE}$ \\
\hline
\end{tabular}

${ }^{\star} \mathrm{p}<0.05,{ }^{* *} \mathrm{p}<0.01,{ }^{* *} \mathrm{p}<0.001$. 
The cost-to-income ratio is the ratio of operating expenses and depreciation to operating income, reflecting the cost of each unit's revenue created by commercial banks. The higher the ratio means the weaker the cost management, the greater the likelihood of liquidity pressure. In theory, the cost-income ratio is inversely proportional to the level of liquidity. The empirical results of the model show a negative correlation between the model 2 and the model 6 and the liquidity level, in line with the expected results. ROA return on assets refers to the bank per unit of assets to create much revenue, reflecting the bank's operating level. The higher the yield of assets, the better the operating state of the bank, the corresponding better able to resolve the liquidity pressure. The regression results showed a positive correlation between the two, consistent with the expected results.

In terms of exogenous control variables, the coefficients of GDP growth rate are significantly negative in both Model 3 and Model 6. Generally speaking, economic growth will bring about loose liquidity, but the opposite is true, indicating that GDP growth is not Alleviate the liquidity pressure of commercial banks. The reason for this may be due to the growth of China's GDP mainly from the pull of investment, investment expansion caused by the increase in the size of the credit makes the possibility of bad debts led to the decline in liquidity levels; In addition the bank "credit" approach May be through the interbank business to circumvent supervision and expansion of the interbank business, business led to liquidity tightening; these two reasons may lead to GDP growth led to bank liquidity tensions.

M2 is significantly negative in both Model 4 and Model 6, but the theory of loose monetary policy should lead to more money delivery to produce liquidity, the two contradictory situations. In this paper, the negative correlation here may be due to the relaxed monetary environment makes the enterprise loans relatively easy, resulting in the bank's credit size increases the possibility of bad debts and lead to liquidity tension; in addition to loose monetary policy to bring liquidity Due to the recent "asset shortage" lack of investment channels and choose to operate in the financial system with the operation of the industry brought about by the liquidity tension.

\section{Conclusion}

According to the analysis above, it is found that the larger banks are better than the smaller banks when it comes to the liquidity condition, indicating that the banks with larger assets are better than the small and medium-sized banks in the liquidity management capacity, and the small and medium-sized commercial banks should strengthen their liquidity management. On the second part of the empirical study, this paper argues that the development of interbank business is the inevitable outcome of commercial bank financial innovation, circumventing supervision and exploring new profit center, but only focusing on the scale of business expansion, ignoring the feasibility and rationality of business development. In view of this situation, this paper makes the following suggestions: 
1) Commercial banks should strengthen the management of maturity mismatches, maintain the symmetry between interbank business assets and interbank liabilities, and avoid further enlargement of liquidity gaps (Wang Xiangyun, 2016). The direction of investment to the lack of liquidity areas like non-standard assets should be reduced and to the other standardized products should be increased.

2) In addition, the way to regulate and the relevant indexes should be improved. Interbank business subjects are constantly changing like interbank deposits, interbank lending, discounted peer bills, and the rapid development business model-buying and selling resale accounts. The corresponding regulatory agencies should maintain a dynamic situation, strengthen the supervision of the interbank business and avoid long cycle inside the financial system.

However, as commercial banks carry out the interbank business to avoid the purpose of supervision, the commercial banks' annual reports have the possibility of concealing the actual real business situation. That may lead the empirical analysis to some mistaken area. What's more, the interbank business is an enormous and continuous innovative business model, which means that this paper is not enough to study the overall of this business. All these areas should be studied in the future.

\section{References}

Calvo, G. A., \& Reinhart, C. M. (1999). Capital Flow Reversals, the Exchange Rate Debate, and Dollarization. MPRA Paper, 36, 13-15.

Diamond, D. W., \& Philip, H. D. (1983). Bank Runs, Deposit Insurance, and Liquidity. Journal of Political Economy, 91, 401-419.

Ercegovac, R., \& Kundid, A. (2011). Interbank Deposit Market Relevance for Croatian Banking System Sustainability. Economic Review, 62, No. 1.

Freixas, X., \& Parigi, B. M. (2000). Jean-Charles Rochet Systemic Risk, Interbank Relations, and Liquidity Provision by the Central Bank. Journal of Money, Credit, Banking, 32, 611-638. https://doi.org/10.2307/2601198

Friedman, M., \& Schwartz, A. J. (1986). The Failure of the Bank of United States: A Reappraisal: A Reply. Explorations in Economic History, 23, 199-204. https://doi.org/10.1016/0014-4983(86)90013-6

Gabriele, T., Amin, M., Mauro, G., \& Dirk, H. (2013). Bankruptcy Cascades in Interbank Markets. PLoS ONE, 7, No. 12.

Georg, C. P. (2013). The Effect of Interbank Network Structure on Contagion and Common Shocks. Journal of Banking \& Finance, 37, 2216-2228. https://doi.org/10.1016/j.jbankfin.2013.02.032

He Yujie, Zhai Guangyu, \& Sun Xiaoxia. 翟光宇, 何玉洁, 孙晓霞. (2015). The Expansion of Chinese Interbank Business and the Risk of Banks-A Empirical Analysis Based on the Data of 2007-2013 中国上市银行同业业务扩张与银行风险一基于 2007-2013 年季度数据的实证分析. Review of Investment Studies, 2, 34-45.

Ramamurti, R. (2012). What Is Really Different about Emerging Market Multinationals? Global Strategy Journal, 2, 41-47. https://doi.org/10.1002/gsj.1025

Wang Peng. 王鹏. (2013). The Business Model of Interbank Business 商业银行同业业 务发展模式比较研究. South Finance Issues, 12, 103-105. 
Wang Xiangyun. 王祥云. (2016). The Risk Study of Interbank Business and Wealth Management Business 银行同业和理财业务流动性风险问题探究. Finance and Economics, 14, 70-72.

Submit or recommend next manuscript to SCIRP and we will provide best service for you:

Accepting pre-submission inquiries through Email, Facebook, LinkedIn, Twitter, etc. A wide selection of journals (inclusive of 9 subjects, more than 200 journals)

Providing 24-hour high-quality service

User-friendly online submission system

Fair and swift peer-review system

Efficient typesetting and proofreading procedure

Display of the result of downloads and visits, as well as the number of cited articles Maximum dissemination of your research work

Submit your manuscript at: http://papersubmission.scirp.org/

Or contactchnstd@scirp.org 